\title{
Oxido-bridged neurosteroid analogues. Synthesis of 2,19-oxido-allopregnanolone
}

\author{
Silvina L. Eduardo, Alberto A. Ghini, and Gerardo Burton* \\ Departamento de Química Orgánica, Facultad de Ciencias Exactas y Naturales, Universidad de \\ Buenos Aires, Pabellón 2, Ciudad Universitaria, C1428EGA Buenos Aires, Argentina \\ E-mail: burton@qo.fcen.uba.ar
}

\begin{abstract}
Dedicated to Professor Edmundo A. Rúveda on his $70^{\text {th }}$ birthday and Professor Roberto A. Rossi on his $60^{\text {th }}$ birthday

(received 28 Aug 03; accepted 15 Oct 03; published on the web 22 Oct 03)
\end{abstract}

\begin{abstract}
3 $\alpha$-Hydroxy-2,19-oxido-5 $\alpha H$-pregnan-20-one was synthesized in 6 steps from the easily available 19-hydroxypregnenolone 3-acetate. The 2,19-oxido bridge was formed in a single step upon spontaneous cyclization and desilylation of a TBDMS protected 19-hydroxy-2 $\alpha, 3 \alpha-$ epoxypregnane. The 4,19-oxido analogue was obtained as a byproduct upon cyclization of the isomeric $3 \alpha, 4 \alpha$-epoxide.
\end{abstract}

Keywords: 2,19-Oxido-allopregnanolone, 4,19-oxido-allopregnanolone, neurosteroid, oxidobridged steroid

\section{Introduction}

Endogenous occurring steroids such as 3 $\alpha$-hydroxy-5 $\alpha H$-pregnan-20-one (allopregnanolone, 1) and its $5 \beta$-isomer (pregnanolone, 2 ) are known to interact with the neuroinhibitory GABA $\mathrm{A}_{\mathrm{A}}$ receptor of the central nervous system. ${ }^{1-3}$ Such neurosteroids and their synthetic analogues can, as a result, demonstrate sedative-hypnotic, anxiolytic or anticonvulsant activities in vivo. In the search of more active, selective and water soluble steroid derivatives, several analogues with improved bioavailability having polar groups at different positions have been developed. ${ }^{4}$ Introduction of $\mathrm{N}$ or $\mathrm{O}$ substituents at the $2 \beta$ position of allopregnanolone does not change significantly the conformation of ring $\mathrm{A}$ and gives rise to active analogues. Thus, minaxolone (3) $)^{5}$ and Org 21465 (4) ${ }^{6}$ are highly effective general anesthetics. 

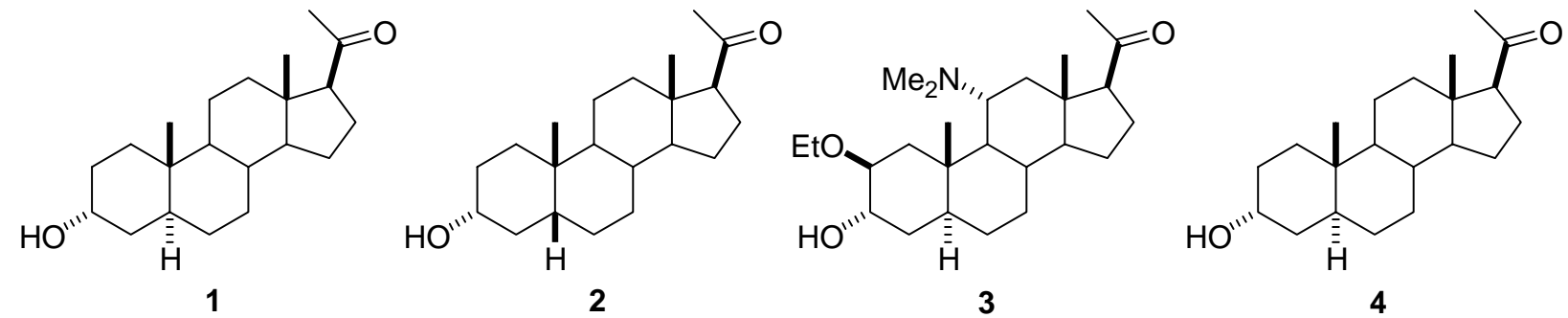

The synthesis of conformationally restrained analogues of biologically active steroids, provides a way of obtaining more potent and/or selective compounds. These compounds also allow a better assessment of the contribution of the overall molecular shape in their binding to the receptor. Although the effect of conformational changes in the biological activity of steroidal hormones has been the subject of several studies, ${ }^{7}$ little is known about their effect in the activity of neurosteroids and neuroactive steroids. ${ }^{8}$ In this regard, we ${ }^{9}$ and others ${ }^{10}$ have recently reported the synthesis and biological activity of several rigid derivatives.

The introduction of an oxido bridge between C-2 and C-19 of allopregnanolone, gives rise to 2,19-oxidopregnane 5, with a distorted A ring bent towards the $\beta$-face. Besides giving a rigid framework, the oxido-bridge may also mimick the apparently well-tolerated $\beta$ oxygen substituent at C-2 as in minaxolone (3). A 4,19-oxidoderivative as $\mathbf{6}$ gives a similar distortion of ring A but with the oxygenated substituent at C-4. Steroids with 2,19-oxido bridges are also potentially useful drugs in breast cancer therapy as suicide substrates for aromatase, the cytochrome P-450 enzyme involved in the final biosynthetic step in the production of estrogens. ${ }^{11}$
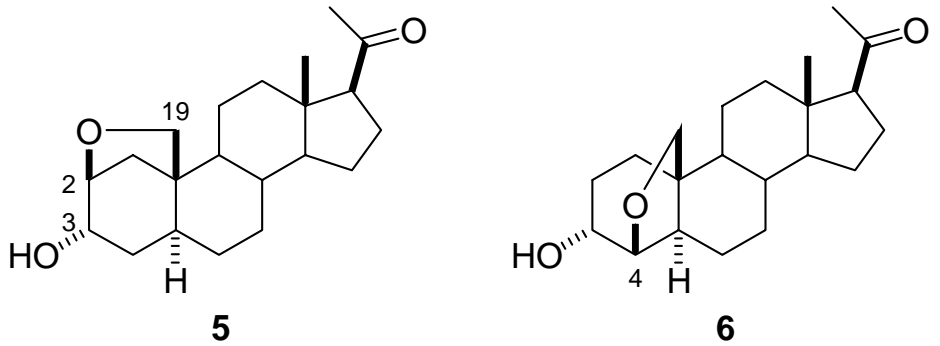

\section{Results and Discussion}

The key step in previous syntheses of substituted analogues of allopregnanolone having polar, electronegative atoms at C-2 $\beta$, has been the attack of a nucleophile on a $2 \alpha, 3 \alpha$-epoxide. ${ }^{5,6}$ Trans diaxial opening of this epoxide accounted for the regioselectivity of the reaction, giving rise to the $3 \alpha-\mathrm{OH}$ moiety, a requisite for $\mathrm{GABA}_{\mathrm{A}}$ receptor activity. The intramolecular version of this process involving a nucleophile attached to C-19, besides being energetically more favorable, would result in the formation of a bridge between positions $2 \beta$ and 19. Thus, epoxide 7a (or a suitably protected precursor as $\mathbf{7 b}$ ) was selected as the key intermediate for obtaining the 2,19oxido-bridged analogue. In a similar way, epoxide $8 a$ should give the 4,19-oxido analogue 6 . 

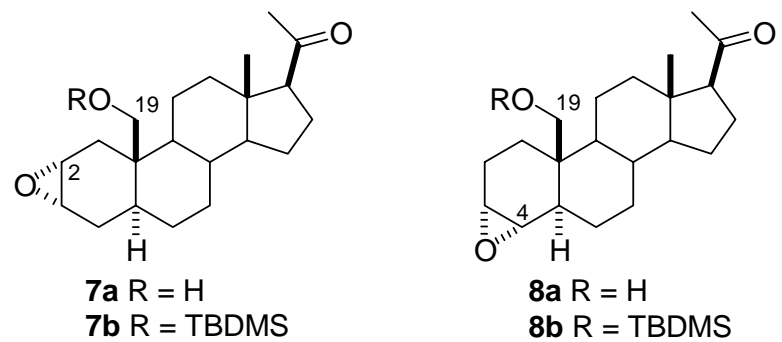

The 19-hydroxysteroid $\mathbf{9}$ was used as starting material. It was obtained from commercially available pregnenolone acetate following essentially the procedure described previously by us for the preparation of the 20-O-acetyloxy analogue. ${ }^{12}$ The synthetic sequence is outlined in Scheme 1. Attempts to hydrogenate the 5,6-double bond in 9 were unsuccesful even at 2-3 bar. The same lack of reactivity was observed with the 19-O-formyloxy and 19-O-acetyloxy derivatives (somewhat less with the latter). However, the $t$-butyldimethylsilyl (TBDMS) ether $\mathbf{1 0}$ was smoothly hydrogenated over $10 \% \mathrm{Pd} / \mathrm{C}$ in ethanol $\left(25{ }^{\circ} \mathrm{C}, 1 \mathrm{bar}\right) ;{ }^{13}$ reduction ocurred as expected from the least sterically demanding $\alpha$-face giving rise stereoselectively to compound $\mathbf{1 1}$ in almost quantitative yield. The stereochemistry at C-5 of $\mathbf{1 1}$ was evident from the $J$ values in the ${ }^{1} \mathrm{H}$ NMR spectrum. The $3 \alpha-\mathrm{H}$ resonance $\left(4.73 \mathrm{ppm} ; W_{1 / 2}=25 \mathrm{~Hz}\right.$ ) was specially diagnostic of the axial position of this hydrogen, indicative of the chair conformation of the A ring in an A/B trans-fused steroid.

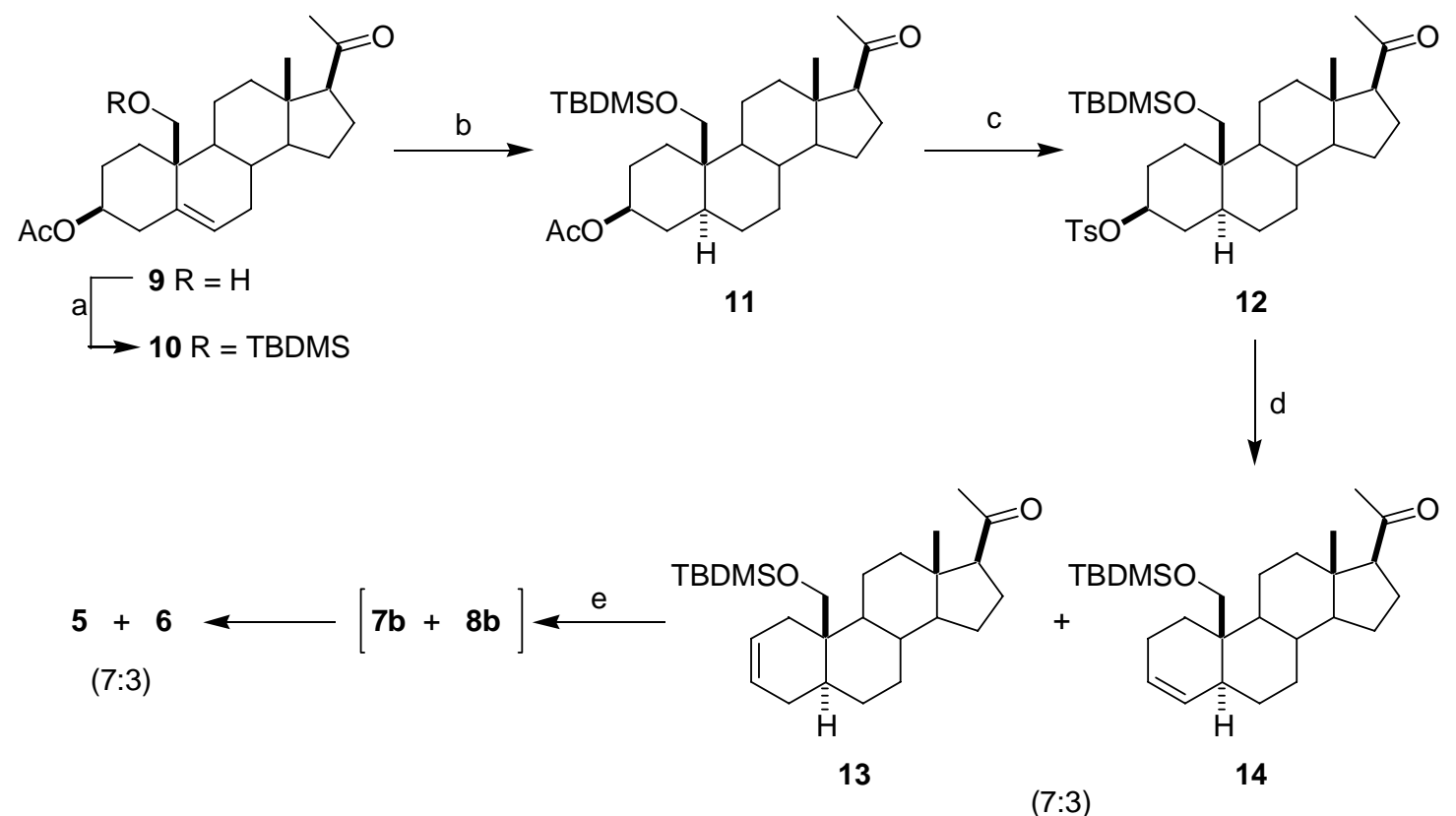

Reagents and conditions. a) TBDMSCI, imidazole, DMF. b) $\mathrm{H}_{2}, 10$ \% Pd/C, EtOH. c) i. 10 $\% \mathrm{NaOH}, \mathrm{MeOH}$; ii. TsCL, py. d) collidine, reflux. e) MCPBA, aqueous $\mathrm{Na}_{2} \mathrm{CO}_{3}, \mathrm{Cl}_{2} \mathrm{CH}_{2}$; ii. Chromatography on silica gel.

\section{Scheme 1}


Double bond formation in ring A was carried out in three steps. Thus, compound $\mathbf{1 1}$ was deacetylated with base and treated with tosyl chloride in anhydrous pyridine giving $95 \%$ of the tosylate 12. Refluxing a solution of $\mathbf{1 2}$ in collidine for $3.5 \mathrm{~h}$ gave a mixture of the desired $\Delta^{2}$ olefin 13 and the minor $\Delta^{3}$ isomer 14 (7:3 ratio by ${ }^{1} \mathrm{H}-\mathrm{NMR}$; 53\% yield from 11). These compounds could not be separated by column chromatography and were used as a mixture in the following step. Treatment of the olefin mixture with $m$-chloroperbenzoic acid (MCPBA) in the presence of sodium carbonate gave the expected $\alpha$-epoxides $\mathbf{7 b}$ and $\mathbf{8 b}$ (from $\mathbf{1 3}$ and $\mathbf{1 4}$, respectively). ${ }^{6,14}$ The ${ }^{1} \mathrm{H}$ NMR spectrum of the crude reaction product showed the characteristic resonances for epoxides at 3.1-3.3 ppm and absence of olefinic hydrogens. The isomeric epoxides had different $\mathrm{R}_{\mathrm{f}}$ on TLC, however when separation was attempted by flash column chromatography an intramolecular attack of the C-19 oxygen occurred, with cleavage of the epoxides and concomitant de-O-silylation (probably catalyzed by the adsorbent). ${ }^{15}$ Thus, compounds 5 and 6 were obtained in one step from 13 and 14. The 7:3 ratio of the products was coincident with that of the precursor olefins. Structures of both compounds were established from ${ }^{1} \mathrm{H}$ and ${ }^{13} \mathrm{C}$ NMR spectra of $\mathbf{5}$ and $\mathbf{6}$ and the correlations in the COSY spectra. Diagnostic signals in the ${ }^{1} \mathrm{H}$ NMR spectra were those assigned to $\mathrm{H}-2$ (for the major product 5) and $\mathrm{H}-4$ (for the minor analogue, 6) at 4.144 and $3.823 \mathrm{ppm}$ respectively, and their long-range correlations with the C-19 hydrogens displayed in the COSY spectra.

Figure 1 shows the AM1 calculated geometries for oxidosteroids $\mathbf{5}$ and $\mathbf{6}$ compared to that of allopregnanolone (1), showing the distortion and bending of ring A. In both steroids the $3 \alpha-$ hydroxyl is displaced upwards and away from its axial orientation resulting in an overall curvature of the molecule towards the $\beta$-face. In the ${ }^{1} \mathrm{H}$ NMR spectrum of $5, \mathrm{H}-2$ appeared as a double doublet $(J=5.0$ and $5.9 \mathrm{~Hz})$, whereas $\mathrm{H}-4$ in 6 was observed as a doublet $(J=4.8 \mathrm{~Hz})$. These data are in accordance with the calculated coupling constants on the above AM1 geometries using the Altona equation $\left(J_{2,1 \alpha}=0.9 \mathrm{~Hz}, J_{2,1 \beta}=6.9 \mathrm{~Hz}\right.$ and $J_{2,3 \beta}=4.5 \mathrm{~Hz}$ for 5 and $J_{4,5 \alpha}=0.5 \mathrm{~Hz}$ and $J_{4,3 \beta}=4.5 \mathrm{~Hz}$ for 6). ${ }^{16}$ An almost perfect "W arrangement" is predicted between one of the hydrogens at position 19 and $\mathrm{H}-5 \alpha$ in $\mathbf{5}$ or $\mathrm{H}-1 \alpha$ in $\mathbf{6}$, these are evident in the multiplicity of the H-19 signals and in the correlations observed in the COSY spectra. 


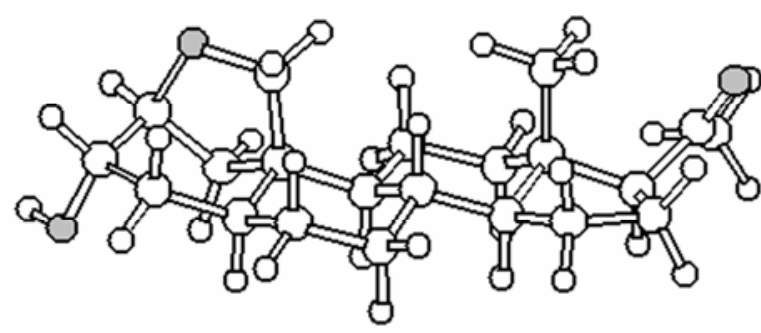

a

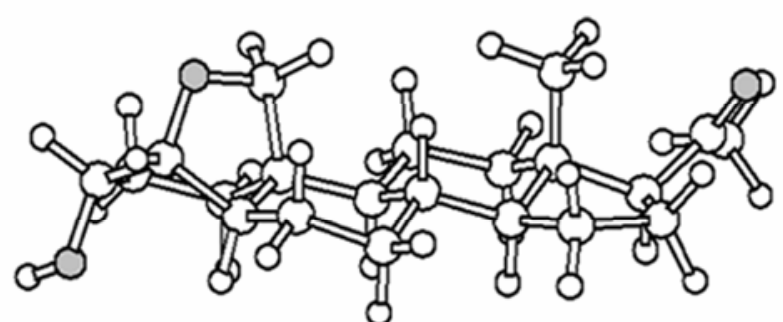

b

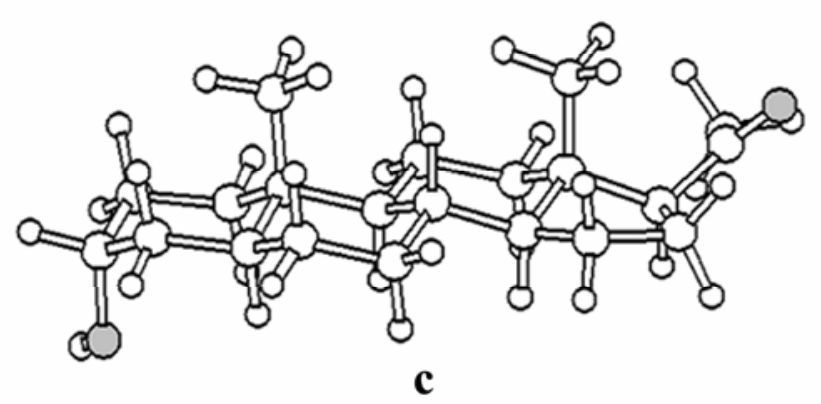

Figure 1. AM1 calculated structures of a) 3 $\alpha$-hydroxy-2,19-oxido-5 $\alpha H$-pregnan-20-one (5), b) $3 \alpha$-hydroxy-4,19-oxido-5 $\alpha H$-pregnan-20-one (6), and c) 3 $\alpha$-hydroxy-5 $\alpha H$-pregnan-20-one (1). Calculations were performed with the MOPAC 97 module in Chem 3D Ultra 5.0.

\section{Conclusions}

The above procedure may be used to introduce 2,19- and 4,19-oxido bridges in a variety of $5 \alpha-\mathrm{H}$ reduced steroids. Furthermore, the change of oxygen by nitrogen or sulfur at C-19, gives easy access to the aza and sulfanyl analogues, respectively.

\section{Experimental Section}

General Procedures. Melting points were determined with a Fisher-Johns apparatus and are uncorrected. NMR spectra were recorded on Bruker AC-200 (4.7 Tesla, $200.13 \mathrm{MHz}$ for ${ }^{1} \mathrm{H}$, $50.32 \mathrm{MHz}$ for ${ }^{13} \mathrm{C}$ ) or AM-500 (11.8 Tesla, $500.13 \mathrm{MHz}$ for ${ }^{1} \mathrm{H}, 125.77 \mathrm{MHz}$ for ${ }^{13} \mathrm{C}$ ) spectrometers in deuteriochloroform. Chemical shifts ( $\delta$ in $\mathrm{ppm}$ ) are given from internal TMS. The $J$ values are given in Hz. Spectra were assigned by analysis of the DEPT, and COSY 45 spectra and by comparison with those of progesterone and other oxido-bridged steroids. ${ }^{9,17,18}$ The electron impact mass spectra (EIMS) were measured on a Shimadzu QP-5000 mass spectrometer at $70 \mathrm{eV}$ by direct inlet. Semiempirical AM1 calculations were performed with the MOPAC 97 module in Chem3D Ultra 5.0 (Cambridge Soft). All solvents used were reagent grade. Solvents were evaporated at ca. $45^{\circ} \mathrm{C}$ under vacuum. Flash column chromatography was carried out on 
silica gel Merck 9385 (0.0040-0.0063 mm). TLC analysis was performed on silica gel 60 F254 (0.2 mm thick). The homogeneity of all compounds was confirmed by TLC.

3ß-Acetyloxy-19-hydroxypregn-5-en-20-one (9). Was prepared in 48\% yield from pregnenolone acetate, following the procedure previously described for 3 $\beta, 20 \beta$-diacetyloxy-19-hydroxypregn5-ene. ${ }^{12} \delta_{\mathrm{H}}(200 \mathrm{MHz}) 0.69\left(\mathrm{H}_{3}-18, \mathrm{~s}\right), 2.04$ (acetate, s), $2.13\left(\mathrm{H}_{3}-21, \mathrm{~s}\right), 3.62\left(\mathrm{H}-19^{\mathrm{b}}, \mathrm{d}, J=\right.$ 11.5), 3.86 (H-19 , d, $J=11.5), 4.65$ (H-3, m), 5.77 (H-6, br s).

3 $\beta$-Acetyloxy-19-(t-butyldimethylsilyloxy)-5 $\alpha H$-pregnan-20-one (11). To a stirred solution of 3 $\beta$-acetyloxy-19-hydroxypregn-5-en-20-one (9) (1.00 g, $2.67 \mathrm{mmol})$ in dry DMF (15 mL) was added imidazole ( $0.544 \mathrm{~g}, 8 \mathrm{mmol})$ and $t$-butyldimethylsilyl chloride $(0.803 \mathrm{~g}, 5.3 \mathrm{mmol})$ under a nitrogen atmosphere. After $24 \mathrm{~h}$ at $25{ }^{\circ} \mathrm{C}$ the mixture was poured onto $\mathrm{HCl}(2 N)$ and extracted with dichloromethane. The organic layer was washed with aqueous $\mathrm{NaCl}$ and water, dried, filtered and evaporated. The solid residue was recrystallized from 2-propanol to give 10 (1.24g, 95\%). $\delta_{\mathrm{H}}(200 \mathrm{MHz}) 0.05\left(\left(\mathrm{CH}_{3}\right)_{2} \mathrm{Si}, \mathrm{s}\right), 0.67\left(\mathrm{H}_{3}-18, \mathrm{~s}\right), 0.87\left(\left(\mathrm{CH}_{3}\right)_{3} \mathrm{CSi}, \mathrm{s}\right), 2.04$ (acetate, s), $2.13\left(\mathrm{H}_{3}-21, \mathrm{~s}\right), 3.59\left(\mathrm{H}-19^{\mathrm{b}}, \mathrm{d}, J=10.4\right), 3.75\left(\mathrm{H}-19^{\mathrm{a}}\right.$, d, $\left.J=10.4\right), 4.64$ (H-3, m), 5.57 (H-6, br s).

A mixture of 10 (1.00 g, $2.04 \mathrm{mmol})$ and $10 \% \mathrm{Pd} / \mathrm{C}(0.1 \mathrm{~g})$ in ethanol $(125 \mathrm{~mL})$ was stirred for 1 day under a hydrogen atmosphere $\left(25{ }^{\circ} \mathrm{C}, 1 \mathrm{bar}\right)$. The catalyst was filtered and the filtrate evaporated to give the $5 \alpha H$-steroid 11 (0.971 g, 97\%), homogeneous by TLC $\left(\mathrm{R}_{\mathrm{f}}=0.60\right.$, hexane/ethyl acetate 7:3). An analytical sample was prepared by recrystallizing 11 from 2propanol, mp 139-141 ${ }^{\circ} \mathrm{C}$. Anal. Calcd. for $\mathrm{C}_{29} \mathrm{H}_{50} \mathrm{O}_{4} \mathrm{Si}$ : C 70.97; $\mathrm{H}$ 10.27. Found C 70.91; $\mathrm{H}$ 10.43. $\delta_{\mathrm{H}}(200 \mathrm{MHz}) 0.06\left(\left(\mathrm{CH}_{3}\right)_{2} \mathrm{Si}, \mathrm{s}\right), 0.61\left(\mathrm{H}_{3}-18, \mathrm{~s}\right), 0.88\left(\left(\mathrm{CH}_{3}\right)_{3} \mathrm{CSi}, \mathrm{s}\right), 2.02$ (acetate, s), $2.11\left(\mathrm{H}_{3}-21, \mathrm{~s}\right), 3.68\left(\mathrm{H}-19^{\mathrm{b}}, \mathrm{d}, J=10.6\right), 3.83\left(\mathrm{H}-19^{\mathrm{a}}, \mathrm{d}, J=10.6\right), 4.73(\mathrm{H}-3, \mathrm{~m}) . \delta_{\mathrm{C}}(50 \mathrm{MHz})-$ 5.1 and $-5.3\left(\left(\mathrm{CH}_{3}\right)_{2} \mathrm{Si}\right), 13.6(\mathrm{C}-18), 18.0\left(\left(\mathrm{CH}_{3}\right)_{3} \mathrm{CSi}\right), 21.4$ (acetate), 22.5 (C-11), 22.7 (C-16), 24.4 (C-15), 25.8 (( $\left.\left.\mathrm{CH}_{3}\right)_{3} \mathrm{CSi}\right), 27.7$ (C-2), 27.9 (C-6), 31.4 (C-7), 31.5 (C-21), 31.9 (C-1), 34.4 (C-4), 35.9 (C-8), 39.0 (C-10), 39.6 (C-12), 44.3 (C-13), 44.6 (C-5), 54.5 (C-9), 57.0 (C-14), 60.2 (C-19), 63.7 (C-17), 73.5 (C-3), 170.7 (acetate) and 209.5 (C-20). m/z (EI) 433 (M - tbutyl), 373 (3), 299 (18), 281 (21), 117 (41), 43 (100).

19-(t-Butyldimethylsilyloxy)-5 $\alpha H$-pregn-2-en-20-one (13) and 19-(t-butyldimethyl silyloxy)$5 \alpha H$-pregn-3-en-20-one (14). To a stirred solution of $5 \alpha$-steroid 11 (0.900 g, $1.83 \mathrm{mmol}$ ) in methanol $(160 \mathrm{ml})$ was added an aqueous solution of $\mathrm{NaOH}(10 \%, 3.7 \mathrm{~mL})$ at $25{ }^{\circ} \mathrm{C}$ under nitrogen. After 2 h the mixture was neutralized with $\mathrm{HCl}(1 N)$, concentrated and extracted with dichloromethane. The organic layer was washed with a saturated solution of $\mathrm{NaCl}$, dried $\left(\mathrm{Na}_{2} \mathrm{SO}_{4}\right)$ and evaporated to give $3 \beta$-hydroxy-19-(t-butyldimethylsilyloxy)-5 $\alpha H$-pregnan-20-one homogeneous by TLC $\left(\mathrm{R}_{\mathrm{f}}=0.60\right.$, hexane/ethyl acetate 4:6), $(0.791 \mathrm{~g}, 96 \%) . \delta_{\mathrm{H}}(200 \mathrm{MHz}) 0.05$ $\left(\left(\mathrm{CH}_{3}\right)_{2} \mathrm{Si}, \mathrm{s}\right), 0.62\left(\mathrm{H}_{3}-18, \mathrm{~s}\right), 0.88\left(\left(\mathrm{CH}_{3}\right)_{3} \mathrm{CSi}, \mathrm{s}\right), 2.11\left(\mathrm{H}_{3}-21, \mathrm{~s}\right), 3.64(\mathrm{H}-3, \mathrm{~m}), 3.66\left(\mathrm{H}-19^{\mathrm{b}}, \mathrm{d}\right.$, $J=10.6), 3.83\left(\mathrm{H}-19^{\mathrm{a}}, \mathrm{d}, J=10.6\right) . \delta_{\mathrm{C}}(50 \mathrm{MHz})-5.1$ and $-5.3\left(\left(\mathrm{CH}_{3}\right)_{2} \mathrm{Si}\right), 13.7(\mathrm{C}-18), 18.1$ (( $\left.\left.\mathrm{CH}_{3}\right)_{3} \mathrm{CSi}\right), 22.7$ (C-11), 22.8 (C-16), 24.5 (C-15), $25.9\left(\left(\mathrm{CH}_{3}\right)_{3} \mathrm{CSi}\right), 28.2$ (C-6), 31.6 (C-21), 31.7 (C-7), 31.8 (C-1), 32.1 (C-2), 36.0 (C-8), 38.6 (C-4), 39.2 (C-10), 39.8 (C-12), 44.4 (C-13), 44.9 (C-5), 54.8 (C-9), 57.2 (C-14), 60.4 (C-19), 63.9 (C-17), 71.3 (C-3), 209.7 (C-20). An ice- 
cooled mixture of the latter compound $(0.700 \mathrm{~g}, 1.56 \mathrm{mmol})$, dry pyridine $(9 \mathrm{ml})$ and tosyl chloride (1.49 g, $7.80 \mathrm{mmol}$ ) was stirred $18 \mathrm{~h}$ under a nitrogen atmosphere. The mixture was poured onto ice-cooled water, extracted with dichloromethane, washed with dilute $\mathrm{HCl}$ and water, dried $\left(\mathrm{Na}_{2} \mathrm{SO}_{4}\right)$, filtered and evaporated to give tosylate 12 (1.031 g, 98\%), homogeneous by TLC $\left(\mathrm{R}_{\mathrm{f}}=0.51\right.$, hexane/ethyl acetate 8:2). $\delta_{\mathrm{H}}(200 \mathrm{MHz}) 0.04\left(\left(\mathrm{CH}_{3}\right)_{2} \mathrm{Si}, \mathrm{s}\right), 0.61\left(\mathrm{H}_{3}-18, \mathrm{~s}\right)$, $0.86\left(\left(\mathrm{CH}_{3}\right)_{3} \mathrm{CSi}, \mathrm{s}\right), 2.11\left(\mathrm{H}_{3}-21, \mathrm{~s}\right), 2.46\left(\mathrm{CH}_{3}-\mathrm{Ar}, \mathrm{s}\right), 3.61\left(\mathrm{H}-19^{\mathrm{b}}, \mathrm{d}, J=10.8\right), 3.79\left(\mathrm{H}-19^{\mathrm{a}}, \mathrm{d}, J\right.$ = 10.8), 4.46 (H-3, m), 7.34 (ArH, d, $J=8.0), 7.81$ (ArH, d, $J=8.0)$.

A stirred solution of 12 (1.031 g, $1.71 \mathrm{mmol}$ ) in collidine (92 mL) was heated under reflux for $3.5 \mathrm{~h}$. The solution was poured onto $\mathrm{HCl}(2 N)$ and extracted with dichloromethane. The organic layer was washed with dilute $\mathrm{HCl}$ and aqueous $\mathrm{NaHCO}_{3}$, dried $\left(\mathrm{Na}_{2} \mathrm{SO}_{4}\right)$, filtered and evaporated under reduced pressure. The solid was purified by flash chromatography to give a mixture of olefins 13 and 14 (0.438 g, 55 \% from 11). An analytical sample of 13 was obtained by recrystallization of the mixture from 2-propanol, mp $134-136{ }^{\circ} \mathrm{C}$. Anal. Calcd. for $\mathrm{C}_{27} \mathrm{H}_{46} \mathrm{O}_{2} \mathrm{Si}$ C 75.29; H 10.76. Found C 74.94; H 10.63. $\delta_{\mathrm{H}}(200 \mathrm{MHz}) 0.03\left(\left(\mathrm{CH}_{3}\right)_{2} \mathrm{Si}, \mathrm{s}\right), 0.63\left(\mathrm{H}_{3}-18, \mathrm{~s}\right)$, $0.87\left(\left(\mathrm{CH}_{3}\right)_{3} \mathrm{CSi}, \mathrm{s}\right), 2.12\left(\mathrm{H}_{3}-21, \mathrm{~s}\right), 3.53\left(\mathrm{H}-19^{\mathrm{a}}, \mathrm{d}, J=10.4\right), 3.81\left(\mathrm{H}-19^{\mathrm{b}}, \mathrm{d}, J=10.4\right), 5.60(\mathrm{H}-$ 2 and $\mathrm{H}-3, \mathrm{~m}) ; \delta_{\mathrm{C}}(50 \mathrm{MHz})-5.1$ and $-5.3\left(\left(\mathrm{CH}_{3}\right)_{2} \mathrm{Si}\right), 13.5(\mathrm{C}-18), 18.1\left(\left(\mathrm{CH}_{3}\right)_{3} \mathrm{CSi}\right), 21.8(\mathrm{C}-$ 11), 22.7 (C-16), 24.4 (C-15), 25.8 (( $\left.\left.\mathrm{CH}_{3}\right)_{3} \mathrm{CSi}\right), 28.6$ (C-6), 30.4 (C-1), 31.4 (C-21), 31.8 (C-7), 34.6 (C-4), 35.9 (C-8), 38.7 (C-10), 39.5 (C-12), 41.5 (C-5), 44.2 (C-13), 54.3 (C-9), 57.3 (C14), 61.3 (C-19), 63.8 (C-17), 125.8 and 126.0 (C-2 and C-3), 209.7 (C-20). m/z (EI): 373 (M- $t$ butyl), 299 (4), 298 (4), 281 (6), 119 (44), 75 (93), 43 (100).

$2 \beta, 19-O x i d o-3 \alpha$-hydroxy-5 $\alpha H$-pregnan-20-one (5) and $4 \beta, 19-o x i d o-3 \alpha$-hydroxy-5 $\alpha H$ pregnan-20-one (6). To the mixture of olefins 13 and 14 (0.100 g, $0.23 \mathrm{mmol})$ obtained above, was added dichloromethane $(6 \mathrm{~mL})$, water $(4 \mathrm{~mL}), \mathrm{Na}_{2} \mathrm{CO}_{3}(0.100 \mathrm{~g})$ and 3-chloroperoxybenzoic acid (0.104 g, $0.603 \mathrm{mmol}$ ) and vigorously stirred at room temperature for $5 \mathrm{~h}$. The mixture was diluted with dichloromethane $(10 \mathrm{ml})$ and the aqueous layer was extracted with dichloromethane. The combined organic extracts were washed with $\mathrm{Na}_{2} \mathrm{SO}_{3}(5 \%)$, saturated aqueous $\mathrm{NaHCO}_{3}$ and water, dried $\left(\mathrm{Na}_{2} \mathrm{SO}_{4}\right)$ and evaporated to give a mixture of $2 \alpha, 3 \alpha$-epoxide $7 \mathbf{b}$ and $3 \alpha, 4 \alpha$-epoxide 8b. Flash column chromatography of the mixture, gave 2,19-oxido steroid 5 (0.028 g, 37 \%), mp $225-228^{\circ} \mathrm{C}$ (from ethyl acetate/hexane). Anal. Calcd. for $\mathrm{C}_{21} \mathrm{H}_{32} \mathrm{O}_{3}$ : C 75.85; $\mathrm{H}$ 9.70. Found C 75.51; H 9.60. $\delta_{\mathrm{H}}(500 \mathrm{MHz}) 0.576\left(\mathrm{H}_{3}-18, \mathrm{~s}\right), 1.373(\mathrm{H}-11 \beta, \mathrm{dq}, J=3.6,12.7), 1.442(\mathrm{H}-12 \alpha$, dt, $J=3.6,12.7 \mathrm{~Hz}), 1.534\left(\mathrm{H}_{2}-4, \mathrm{~m}\right), 1.684$ (H-5, m), 1.738 (H-1 $\left.\alpha, \mathrm{d}, J=11.4\right), 1.764(\mathrm{H}-11 \alpha$,

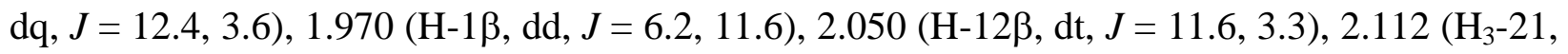
s), $2.515(\mathrm{H}-17, \mathrm{t}, J=9.1), 3.643\left(\mathrm{H}-19^{\mathrm{a}}\right.$, dd, $\left.{ }^{3} J=8.0,{ }^{4} J=0.6\right), 3.756\left(\mathrm{H}-19^{\mathrm{b}}, \mathrm{d}, J=8.2\right), 3.899$ $\left(\mathrm{H}-3\right.$, br s, $\left.\mathrm{W}_{1 / 2}=11 \mathrm{~Hz}\right), 4.144(\mathrm{H}-2, \mathrm{dd}, J=5.0,5.9)$; $\delta_{\mathrm{C}}(125 \mathrm{MHz}) 13.2(\mathrm{C}-18), 21.0(\mathrm{C}-11)$, 22.9 (C-16), 24.3 (C-15), 29.9 (C-6), 31.3 (C-7), 31.5 (C-21), 34.8 (C-1), 35.5 (C-4), 38.4 (C-8), 38.7 (C-12), 39.8 (C-5), 43.9 (C-13), 46.2 (C-9), 46.9 (C-10), 56.8 (C-14), 63.7 (C-17), 66.4 (C19), 68.6 (C-3), 77.6 (C-2), 209.4 (C-20). m/z (EI): 332 (M+1, 13\%), 314 (2), 302 (2), 273 (7), 245 (5), 55 (23), 43 (100). 
Further elution gave 4,19-oxido steroid 6 (0.013g, 17\%), mp 208-210 ${ }^{\circ} \mathrm{C}$ (from ethyl acetate/hexane). Anal. Calcd. for $\mathrm{C}_{21} \mathrm{H}_{32} \mathrm{O}_{3}$ : C 75.85; H 9.70. Found C 75.65; H 9.92;. $\delta_{\mathrm{H}}(500$

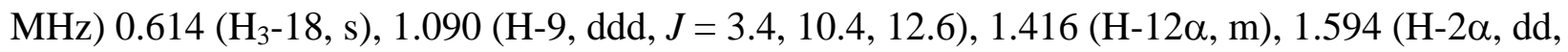

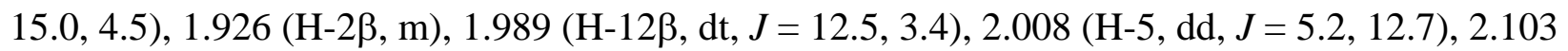
$\left(\mathrm{H}_{3}-21, \mathrm{~s}\right), 2.524(\mathrm{H}-17, \mathrm{t}, J=9.0), 3.634\left(\mathrm{H}-19^{\mathrm{a}}, \mathrm{d}, J=8.0\right), 3.823(\mathrm{H}-4, \mathrm{~d}, J=4.8), 3.875(\mathrm{H}-$ $19^{\mathrm{b}}$, dd, $\left.{ }^{3} J=8.2,{ }^{4} J=1.8\right), 3.946(\mathrm{H}-3$, br t, $J=4.3) . \delta_{\mathrm{C}}(125 \mathrm{MHz}) 13.6(\mathrm{C}-18), 22.8(\mathrm{C}-11)$, 23.5 (C-16), 24.2 (C-15), 29.6 (C-6), 32.3 (C-7), 31.5 (C-21), 30.8 (C-1), 35.5 (C-2), 36.4 (C-8), 39.2 (C-12), 44.0 (C-5), 44.4 (C-13), 45.6 (C-10), 47.7 (C-9), 55.8 (C-14), 63.8 (C-17), 69.0 (C3), 69.7 (C-19), 83.5 (C-4), 209.6 (C-20). m/z (EI): 332 (M+1 37), 317 (7), 314 (6), 302 (18), 287 (12), 274 (26), 273 (100), 230 (9).

\section{Acknowledgments}

We thank Universidad de Buenos Aires and CONICET for financial support. One of us (S.L.E.) also thanks Universidad de Buenos Aires for a fellowship.

\section{References and Notes}

1. Gasior M.; Carter R. B.; Witkin J. M. Trends Pharmacol. Sci. 1999, 20, 107.

2. Lambert, J. J.; Belelli, D.; Hill-Venning, C.; Peters, J. A. Trends Pharmacol. Sci. 1995, 16, 295.

3. Hamilton, N. M. Curr. Topics Med. Chem. 2002, 2, 887.

4. Beekman M.; Ungard J. T.; Gasior M.; Carter R. B.; Dijkstra D.; Golberg S. R.; Witkin J. M. J. Pharmacol. Exp. Ther. 1998, 284, 868.

5. Phillips, G. H.; Ayres, B. E.; Bailey, E. J.; Ewan, G. B.; Looker, B. E.; May, P. J. J. Steroid Biochem. 1979, 11, 79.

6. Anderson, A.; Boyd, A. C.; Campbell, A. C.; Gemmel, D. K.; Hamilton, N. M.; Hill, D. R.; Hill-Venning, C.; Lambert, J. J.; Maidment, M. S.; May, V.; Marshall, R. J.; Peters, J. A.; Rees, D. C.; Stevenson, D.; Sundaram, H. J. Med. Chem. 1997, 40, 1668.

7. Burton, G.; Galignana, M. D.; de Lavallaz, S.; Brachet-Cota, A. L.; Sproviero, E. M.; Ghini, A. A.; Lantos, C. P.; Damasco, M. C. Mol. Pharmacol. 1995, 47, 535

8. See for example Stone T. W. Ed. CNS Neurotransmitters and Neuromodulators. Neuroactive Steroids, Chapters 2 and 4, CRC Press, 1996.

9. Veleiro, A. S.; Rosenstein, R.; Jaliffa, C.; Grilli, M. L.; Speroni, F.; Burton, G. Bioorg. Med Chem. Letters 2003, 13, 343.

10. Anderson, A.; Boyd, A. C.; Clark, J. K.; Fielding, L; Gemmell, D. K.; Hamilton, N. M.; Maidment, M. S.; May, V.; McGuire, R.; Mc Phail, P.; Sansbury, F. H.; Sundaram, H.; Taylor, R. J. Med. Chem. 2000, 43, 4118. 
11. Burkhart, J.P.; Huber, E.W.; Laskovics, F.M.; Peet, N.P. J. Org. Chem. 1992, 57, 5150.

12. Joselevich, M.; Ghini, A. A.; Burton, G. Org. Biomol. Chem. 2003, 1, 939.

13. In the TBDMS derivative 10, any interaction between the double bond and the C-19 oxygen would be absent, as the voluminous TBDMS group is oriented anti to the C10-C5 bond, i.e. away from the double bond.

14. The TBDMS protecting group adds additional steric hindrance to any attack from the $\beta$-face.

15. Spontaneous cyclization of the epoxide mixture to give $\mathbf{5}$ and $\mathbf{6}$ was also observed on standing, after several days at room temperature.

16. Haasnoot, C. A. G.; de Leew, F. A. A. M.; Altona, C. Tetrahedron 1980, 36, 2783.

17. Wong, T. C.; Rutar, V. J. Am. Chem. Soc. 1984, 106, 7380.

18. Brachet-Cota, A. L. and Burton, G. Z. Naturforsch. 1990, 45b, 711. 